\title{
OVER 18\% EFFICIENT MC-SI SOLAR CELLS FROM 100\% SOLAR GRADE SILICON FEEDSTOCK FROM A METALLURGICAL PROCESS ROUTE
}

\author{
M. Kaes ${ }^{1}$, G. Hahn ${ }^{1}$, K. Peter ${ }^{1}$, E. Enebakk ${ }^{2}$ \\ ${ }^{1}$ University of Konstanz, Department of Physics, 78457 Konstanz, Germany \\ ${ }^{2}$ Elkem Solar AS, Fiskaaveien 100, N-4675 Kristiansand, Norway
}

\begin{abstract}
Based on very promising results for solar cells manufactured in an industrial process reaching 16\% efficiency we analyzed if solar grade (SoG) silicon feedstock is capable to match up with electronic grade silicon in high efficiency ranges. Thus we applied a reliable lab-type process on $5 \times 5 \mathrm{~cm}^{2}$ wafers resulting in $2 \times 2 \mathrm{~cm}^{2}$ untextured solar cells with an efficiency limit of $18.5 \%$ for floatzone (FZ) references. The $5 \times 5 \mathrm{~cm}^{2}$ wafers were selected out of $12.5 \times 12.5 \mathrm{~cm}^{2}$ phosphorous pregettered SoG-Si wafers characterized by lifetime measurements. The best solar cell out of $100 \%$ Elkem SoG-Si reached $\eta=18.1 \%$ stable efficiency certified by FhG-ISE CalLab. This is the highest value for this material reported so far.
\end{abstract}

\section{INTRODUCTION}

Within the last years the major part of the silicon feedstock for PV was provided by the electronic industry as electronic grade silicon residues of high quality. As the PV market volume increases by more than $30 \%$ every year, the demand of silicon increases accordingly. This demand cannot be fulfilled by the surplus of the electronic industry anymore and therefore a new cost effective refining for silicon feedstock especially produced for the solar industry is needed. One way can be the newly developed solar grade silicon feedstock from a metallurgical process route by Elkem.

The new feedstock under investigation will enable dedicated feedstock volumes for PV-industry and opens the route for cost reductions and mass production of PVmodules. The investment cost for an industrial scale feedstock production plant is expected to be significantly reduced compared to the investment for a comparable production plant based on silane or trichlorosilane technology. Likewise, the operating cost is expected to be comparably low. The energy payback period is dominated by the energy used to purify and crystallize the base silicon. Therefore the low energy consumption of the metallurgical process route is an additional favorable factor which will result in shorter energy recovery time for the resulting PV installations. The energy consumption for a future metallurgical refining plant is calculated to be in the range of $25 \mathrm{kWh} / \mathrm{kg}$ and the energy payback time could accordingly be cut to half (two years or less for middle Europe), if 100\% Elkem feedstock is used for the production of the module. A module from Elkem-Si will produce at least $5 \%$ more energy during its life period (25 years) as compared to the modules out of electronic grade silicon (EG-Si). However, solar cell manufacturers are doubtful if SoG-Si can compete with EG-Si concerning quality of the feedstock.

\section{ELKEM SOLAR SILICON TECHNOLOGY}

The SoG-Si technology route followed by Elkem has been reported in [1]. As illustrated in Fig. 1, commercial metallurgical grade silicon melt from Elkem's electric arc furnace was treated with pyro- and hydro-metallurgical refining processes including slag treatment, alloying and leaching. The resulting solar grade silicon crystals are molten and further refined before crushing and sizing to suit ingot preparation in the following step.

Silicon wafers used for this contribution are cut out of $265 \mathrm{~kg}$ block cast ingots grown by directional solidification. One ingot used has a weight mixture of $75 \%$ Elkem SoG$\mathrm{Si}$ and $25 \% \mathrm{EG}-\mathrm{Si}$ and the other ingot consists of $100 \%$ Elkem SoG-Si.

\begin{tabular}{|l|l|}
\hline \multicolumn{1}{|c|}{ Process step } & \multicolumn{1}{c|}{ Description } \\
\hline Elkem Silicon Metal & $\begin{array}{l}\text { - Elkem Silicon globally largest } \\
\text { supplier }\end{array}$ \\
\hline $\begin{array}{l}\text { Pyro-metallurgical } \\
\text { refining }\end{array}$ & - Energy efficient refining \\
\hline $\begin{array}{l}\text { Hydro-metallurgical } \\
\text { refining }\end{array}$ & $\begin{array}{l}\text { - Run in industrial scale today } \\
\text { (Silgrain }^{\circledR} \text { ) }\end{array}$ \\
\hline $\begin{array}{l}\text { Final polishing } \\
\text { tomer specification. }\end{array}$ \\
\hline \\
\hline
\end{tabular}

Fig. 1: Metallurgical refining process by Elkem. 


\section{LIFETIME ANALYSIS}

Using an industrial screen printing cell process effciencies $\eta>16 \%$ have been demonstrated on $12.5 \times 12.5 \mathrm{~cm}^{2}$ solar cells from $100 \%$ SoG-Si feedstock [2]. A high quality of this material is obtained within a huge fraction of the ingot (see Fig. 2). To assess the electronic quality of this material, lifetime measurements have been carried out on neighboring wafers after a P-gettering step. For the measurement the surfaces were passivated with $\mathrm{SiN}$ to suppress surface recombination and to measure the bulk lifetimes.

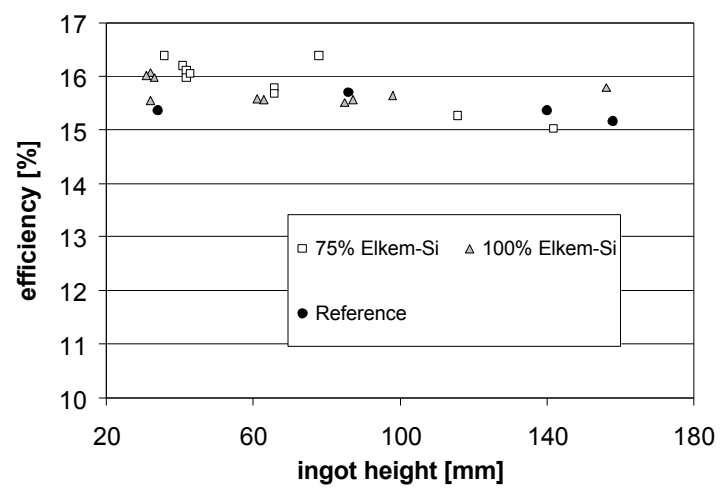

Fig. 2: Solar cell efficiencies $\left(12.5 \times 12.5 \mathrm{~cm}^{2}\right)$ dependent on wafer position in the brick from bottom to top achieved on feedstock from $75 \%$ and $100 \%$ Elkem-Si and reference EG-Si respectively, presented in [4].

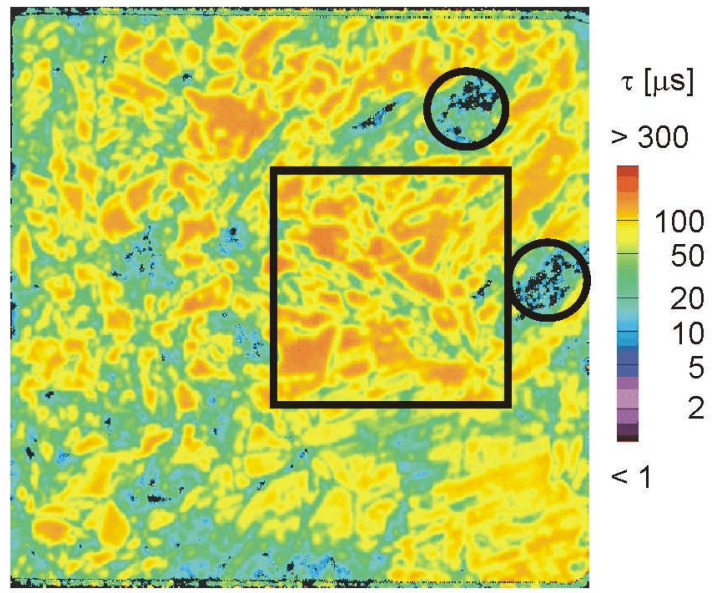

Fig. 3: Bulk lifetime mapping of a $12.5 \times 12.5 \mathrm{~cm}^{2}$ silicon wafer from $100 \%$ SoG-Si feedstock. The $5 \times 5 \mathrm{~cm}^{2}$ wafer for the lab-type solar cell process is originating from the marked square.

Both wafers presented in Fig. 3 and 4 show large areas of good material quality that are capable to process solar cells of high quality.

Solar cells of high quality have already been processed with an industrial type process on neighboring wafers despite of these areas of lower lifetimes [2]. Results can be seen in table 1 .

\begin{tabular}{|c|c|c|c|}
\hline $\mathbf{V}_{\text {oc }}[\mathbf{m V}]$ & $\mathbf{j}_{\mathbf{s c}}\left[\mathbf{m A} / \mathbf{c m}^{2}\right]$ & FF [\%] & $\eta[\%]$ \\
\hline 628 & 33.9 & 75.4 & 16.0 \\
\hline
\end{tabular}

Table 1: IV data of a $125 \times 125 \mathrm{~mm}^{2}$ textured industrial type solar cell processed on a neighboring wafer of the wafer characterized in Fig. 3.

For the lab-type solar cell process the $5 \times 5 \mathrm{~cm}^{2}$ areas illustrated as black squares were selected and cut out. Regions of lower lifetime values are partly identified as recombination active grain boundaries in the LBIC measurements (Fig. 8).

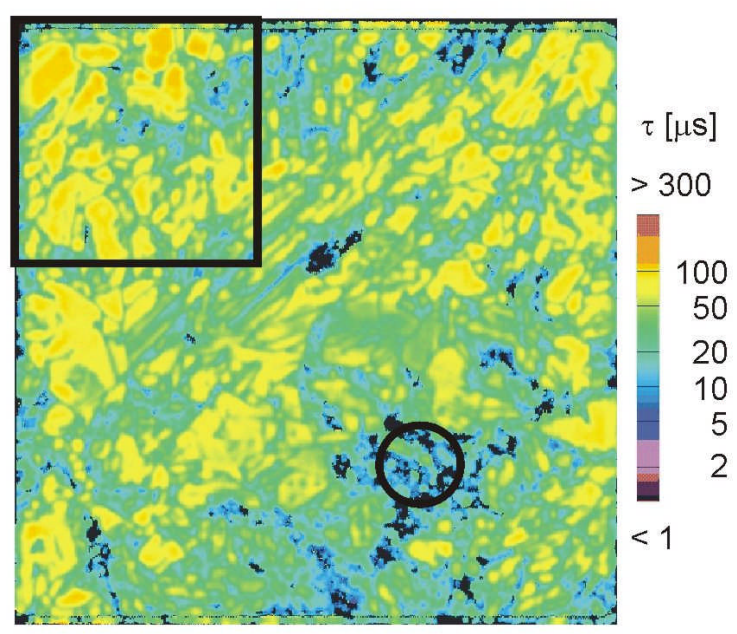

Fig. 4: Bulk lifetime mapping of a $12.5 \times 12.5 \mathrm{~cm}^{2}$ silicon wafer from $75 \%$ SoG-Si feedstock. The $5 \times 5 \mathrm{~cm}^{2}$ wafer for the lab-type solar cell process is originating from the marked square.

\section{HIGH EFFICIENCY SOLAR CELL PROCESS}

We developed a solar cell process designed for multicrystalline silicon wafers of standard material quality with photolithographically defined front grid. This process contains no high temperature steps above $900^{\circ} \mathrm{C}$ to avoid the dissolving of impurity clusters. The concentration of iron and other distributed impurities, always occurring in multicrystalline $(\mathrm{mc})$ silicon wafers after the crystal growth process, are considerably decreased by a phosphorous diffusion gettering step for emitter formation leading to increased lifetimes [2]. Remaining impurities and crystal defects present after a gettering step can keep the minority carrier lifetimes low in certain areas but can partly be neutralized by hydrogenation.

Experiments on edge defined film-fed growth and string ribbon silicon wafers showed that hydrogenation at high temperatures by firing a hydrogen rich silicon nitride is more effective than hydrogenation at lower temperatures by a microwave induced remote hydrogen plasma (MIRHP) [3]. Although hydrogenation plays a less important role for block cast $\mathrm{mc}-\mathrm{Si}$, this kind of hydrogenation is implemented as the last high temperature step in the processing sequence of multicrystalline silicon wafers. 


\section{Processing sequence}

The solar cell process in Fig. 5 has changed slightly compared to the process already presented in [4]. The contact sintering at $380^{\circ} \mathrm{C}$ for one hour in $\mathrm{Ar} / \mathrm{H}_{2}$ ambient is redundant if the MIRHP step is introduced.

Four $2 \times 2 \mathrm{~cm}^{2}$ solar cells are cut out of each $5 \times 5 \mathrm{~cm}^{2}$ wafer at the end of the process. The subsequent MIRHP step passivates the diced pn-junction at the edge [3], gives additional bulk hydrogenation [4] and serves for contact sintering. In the last step $\mathrm{MgF}_{2}$ as a second antireflection layer can be evaporated to improve optical performance.

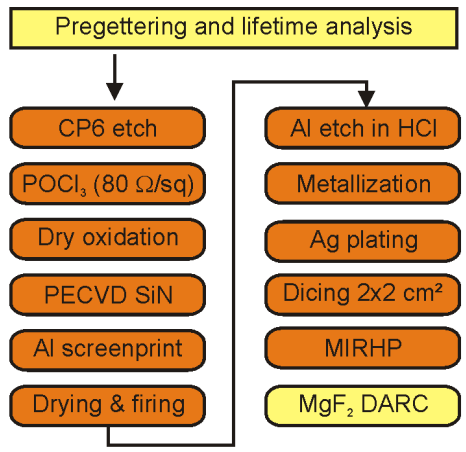

Fig. 5: Processing sequence of the photolithography based solar cell process.

\section{Lab-type vs. industrial type processing}

The lab-type process illustrated in Fig. 5 has several advantages compared to a standard industrial process for $\mathrm{mc}$ without texturing. The high efficiency emitter of about $80 \Omega /$ sq gives a better blue response, decreasing recombination at the front surface thus increasing short circuit current. However, several groups already carry out efforts to replace the $50 \Omega / \mathrm{sq}$ emitter used in standard industrial processing with emitters of noticeably higher sheet resistance.

The thermal oxidation gives only a small increase of about $0.1-0.2 \%$ absolute in efficiency [3] and can in principle be omitted. The SiN layer deposition, the Al screen printing and the drying and firing process steps are identical to industrial processing, except for a higher refractive index and a thinner thickness for the PECVD-SiN layer optimized for the DARC.

A strong improvement is achieved by the photolithographically defined metallization. Hereby the SiN layer is opened to evaporate metal fingers consisting of $\mathrm{Ti} / \mathrm{Pd} / \mathrm{Ag}$ with a thickness of $50 \mathrm{~nm}$ for each metal. The 25 metal fingers with ideally $10 \mathrm{~nm}$ thickness are thickened by about 5-7 $\mu \mathrm{m}$ by Ag plating. Including the Busbar a shadowing of about $4-4.5 \%$ is achieved together with a low series resistance $R_{\text {Ser }}<0.5 \Omega \mathrm{cm}^{2}$. Compared to a shadowing of about $7-8 \%$ in industrial processing an increase of $1.1-1.3 \mathrm{~mA} / \mathrm{cm}^{2}$ can be reached. Low series resistance and high shunt resistance $\left(R_{S h}>10^{6} \Omega \mathrm{cm}^{2}\right)$ lead to an improvement in fill factor by about $2-3 \%$ reaching $\mathrm{FF}=79-80 \%$. With advanced industrial metallization techniques like buried contacts comparably low shadowing can be achieved.
The dicing of the solar cells to $2 \times 2 \mathrm{~cm}^{2}$ gives a disadvantageously high edge-to-area ratio leading to high second diode current density in the order of $2 * 10^{-8} \mathrm{~A} / \mathrm{cm}^{2}$ due to edge currents. A subsequent MIRHP process step can partly passivate these edge currents reducing jo2 and resulting in an increase of about $1 \%$ absolute in fill factor [3].

A further strong increase is gained by the DARC giving an increase in $j_{\mathrm{sc}}$ of about $1.5 \mathrm{~mA} / \mathrm{cm}^{2}$ compared to an untextured industrial type processed solar cell. The used $\mathrm{MgF}_{2}$ as second layer of the DARC can be compared to the glass on top of the industrial solar cell after encapsulation into a solar cell module.

Regarding an industrially processed untextured solar cell reaching an efficiency of about $16 \%$ the displayed labtype process should lead to efficiencies of about $18 \%$.

Further improvements should be feasible by introducing a texture and an advanced photolithography reducing the shadowing to $3 \%$ and below. Another bottleneck in this process is the unsatisfying high recombination at the rearside by the Al-BSF which can be overcome by full rearside passivation including local rear contacts.

\section{Optical properties}

Fig. 6 shows a PC1D simulation for the $\mathrm{SiO}_{2}-\mathrm{SiN}$ $\mathrm{MgF}_{2}$ film system for 3 different $\mathrm{SiO}_{2}$ thicknesses $(0,10$, and $15 \mathrm{~nm}$ ). Parameters for the simulation are chosen corresponding to the process as defined in Fig. 5 for a $210 \mu \mathrm{m}$ thick FZ solar cell with $0.8 \Omega \mathrm{cm}$ resistivity and $300 \mu$ s bulk lifetime reaching $18.5 \%$ efficiency.

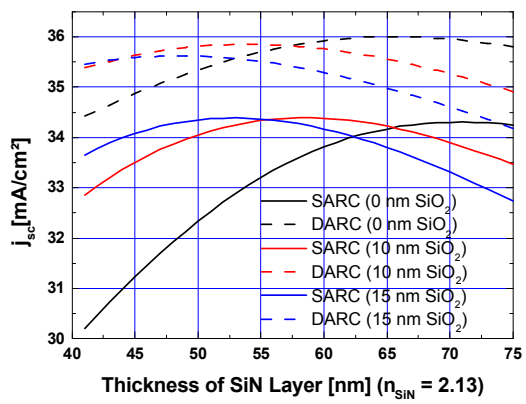

Fig. 6: PC1D simulation for the antireflection coating for three different $\mathrm{SiO}_{2}$ thicknesses.

Shown is the short circuit current density versus the $\mathrm{SiN}$ thickness on top of the $\mathrm{SiO}_{2}$ film (SARC = single layer antireflection coating). The DARC curves (double layer antireflection coating) show the short circuit current density versus the $\mathrm{SiN}$ thickness with an additional $\mathrm{MgF}_{2}$ layer $\left(n_{\mathrm{MgF} 2}=1.38\right)$ of optimal thickness on top of the SiN layer. To get the highest $j_{s c}$ with the DARC the SiN layer has to be thinner as the layer for a SARC used in PV industry. A SARC with a SiN thickness optimized for the DARC results in a $0.2-0.5 \mathrm{~mA} / \mathrm{cm}^{2}$ lower $\mathrm{j}_{\mathrm{sc}}$ compared to a SARC with a SiN thickness optimized for a SARC only.

Introducing a thin $\mathrm{SiO}_{2}$ layer $\left(\mathrm{n}_{\mathrm{SiO}}=1.46\right)$ of $10 \mathrm{~nm}$ thickness reduces $j_{s c}$ by about $0.15 \mathrm{~mA} / \mathrm{cm}^{2}$ for the DARC, a $15 \mathrm{~nm} \mathrm{SiO}$ reduces $j_{\text {sc }}$ by already $0.4 \mathrm{~mA} / \mathrm{cm}^{2}$. Thus, if introducing a thermal oxidation for a better surface passivation the $\mathrm{SiO}_{2}$ thickness has to be as thin as possible. 
The SiN layer is used as hydrogen source for hydrogenation during the firing step. Using a different type of hydrogenation (e.g. hydrogenation by remote hydrogen plasma or a SiN layer present on the rear-side during firing) the SiN layer on the front could be replaced by a ZnS layer $\left(\mathrm{n}_{\mathrm{ZnS}}=2.34\right)$ giving a lower reflection with an increase in $j_{\mathrm{sc}}$ of about $0.5-0.7 \mathrm{~mA} / \mathrm{cm}^{2}$.

The refraction indexes of all considered layers are changing slightly within the spectral wavelength. For the simulation constant values were used with the refractive indexes taken at $600 \mathrm{~nm}$.

The evaporation of $\mathrm{MgF}_{2}$ is usually done only for selected solar cells. Thus the simulation gives a useful prediction what can be expected as gain in $\mathrm{j}_{\mathrm{sc}}$ after the $\mathrm{MgF}_{2}$ evaporation for the characterized solar cells with only a SARC. Depending on the SiN thickness the increase is about 1.4-1.8 mA/cm ${ }^{2}$, equivalent to an increase of about $0.8-0.9 \%$ in efficiency. Actually in experiments an increase of about $0.9-1.1 \%$ in efficiency on FZ samples is observed probably caused by the changing refractive indexes. With decreasing bulk quality $j_{s c}$ itself and the difference in $j_{s c}$ between SARC and DARC is decreasing.

\section{RESULTS}

According to the process illustrated in Fig. 5 two $5 \times 5 \mathrm{~cm}^{2} \mathrm{mc}$ wafer $(\sim 0.8 \Omega \mathrm{cm})$ from Elkem SoG-Si feedstock out of a center brick of a standard block cast ingot were processed. To evaluate the efficiency limit of this SoG-Si material pregettered and characterized material was chosen (see Fig. 3 and 4). The results after the MIRHP step are presented in table 2.

\begin{tabular}{|c|c|c|c|c|}
\hline $\begin{array}{c}\text { Feedstock } \\
\text { (center brick) }\end{array}$ & $\begin{array}{c}\mathbf{V}_{\text {oc }} \\
{[\mathbf{m V}]}\end{array}$ & $\begin{array}{c}\mathbf{j}_{\mathbf{s c}} \\
{\left[\mathbf{m A} / \mathbf{c m}^{2} \mathbf{}\right.}\end{array}$ & $\begin{array}{c}\mathbf{F F} \\
{[\%]}\end{array}$ & $\begin{array}{c}\boldsymbol{\eta} \\
{[\%]}\end{array}$ \\
\hline $100 \%$ SoG (a) & 639 & 33.3 & 79.9 & 16.9 \\
\hline $100 \%$ SoG (b) & 641 & 33.3 & 80.4 & 17.1 \\
\hline $100 \%$ SoG (c) & 638 & 33.4 & 79.1 & 16.9 \\
\hline $100 \%$ SoG (d) & 642 & 33.3 & 80.4 & 17.2 \\
\hline $75 \%$ SoG & 631 & 33.3 & 79.4 & 16.7 \\
\hline $75 \%$ SoG & 636 & 33.4 & 79.3 & 16.9 \\
\hline $75 \%$ SoG & 635 & 33.3 & 79.0 & 16.7 \\
\hline $75 \%$ SoG & 634 & 33.1 & 79.7 & 16.7 \\
\hline
\end{tabular}

Table 2: IV data with SiN coating. a-d: see Fig. 8.

\begin{tabular}{|c|c|c|c|c|}
\hline Feedstock & $\begin{array}{c}\mathbf{V}_{\text {oc }} \\
{[\mathbf{m V}]}\end{array}$ & $\begin{array}{c}\mathbf{j}_{\mathbf{s c}} \\
{\left[\mathbf{m A} / \mathbf{c m}^{2}\right]}\end{array}$ & $\begin{array}{c}\mathbf{F F} \\
{[\%]}\end{array}$ & $\begin{array}{c}\boldsymbol{\eta} \\
{[\%]}\end{array}$ \\
\hline $100 \%$ SoG (a) & 641 & 35.3 & 79.6 & 18.0 \\
\hline $100 \%$ SoG (b) & 644 & 35.6 & 80.5 & 18.5 \\
\hline $100 \%$ SoG (c) & 640 & 35.4 & 79.2 & 17.9 \\
\hline $100 \%$ SoG (d) & 644 & 35.6 & 80.3 & 18.4 \\
\hline $0.8 \Omega \mathrm{cm} \mathrm{FZ(a)}$ & 636 & 35.9 & 79.3 & 18.1 \\
\hline $0.8 \Omega \mathrm{cm} \mathrm{FZ} \mathrm{(b)}$ & 638 & 36.0 & 78.9 & 18.2 \\
\hline $0.8 \Omega \mathrm{cm} \mathrm{FZ(c)}$ & 638 & 36.0 & 80.1 & 18.4 \\
\hline $0.8 \Omega \mathrm{cm} \mathrm{FZ(d)}$ & 638 & 36.0 & 80.4 & 18.5 \\
\hline
\end{tabular}

Table 3: IV data after evaporation of the second antireflection layer and an anneal step for 10 minutes at $200^{\circ} \mathrm{C}$.
The thickness of the PECVD SiN is optimized for a double layer antireflection coating. The IV data of the $100 \%$ SoG-Si solar cells after evaporation of the second antireflection layer are presented in table 3 together with IV data of reference floatzone (FZ) solar cells.

\section{Process limitations}

The comparison with the FZ solar cells reveals that efficiencies of the SoG-Si cells are limited by the chosen process and not by the material itself. Performance losses within the process are the unsatisfying optical performance due to not optimal matching of the DARC structure and a missing surface texture together with a relatively high surface recombination velocity at the rear side by the full rear side aluminium alloying for Al-BSF formation. In addition, a relatively low emitter sheet resistance of $75 \Omega$ /sq leads to an unnecessarily high emitter recombination current. Cell separation by dicing is a further limitation of the process, as it causes an open pn-junction at the cell's edges.

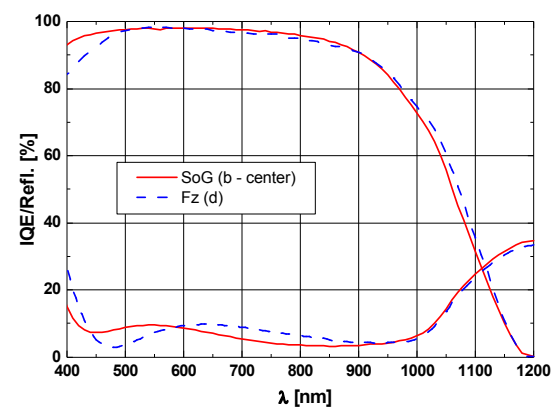

Fig. 7: IQE and reflection of the best $2 \times 2 \mathrm{~cm}^{2}$ solar cell from $100 \%$ SoG-Si (cell b) and the best FZ reference solar cell (cell d).

\section{LBIC measurements}

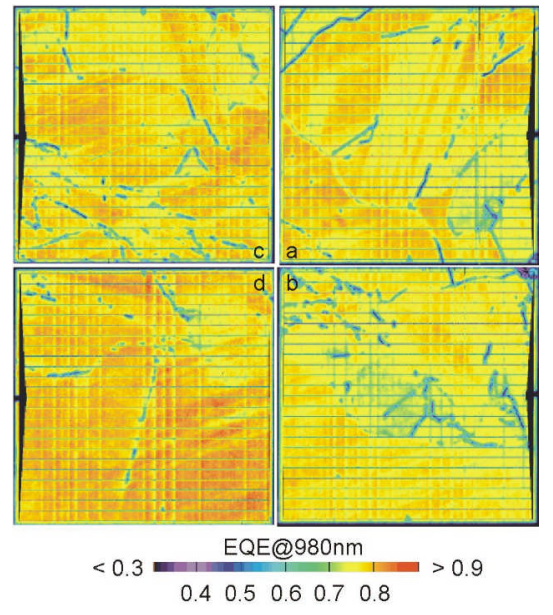

Fig. 8: LBIC measurements of the four solar cells from 100\% SoG-Si feedstock after DARC deposition. The best cell (b) was measured in a degraded state resulting in a lower signal in the high lifetime areas. 
The LBIC measurements show a good correlation to lifetime measurements of a neighboring wafer illustrated in Fig. 3. Only parts of the grain boundaries seem to be recombination active in contrast to standard mc material. The observed slight degradation is due to a homogeneous reduction of lifetimes in the best wafer areas.

Although all four cells show recombination active areas, the obtained open circuit voltages are extremely high for the solar cell process used, even higher than for the reference $F Z$ material in the same resistivity class. This will be subject to further investigations.

\begin{tabular}{|c|c|c|c|c|}
\hline Best cell & $\begin{array}{c}\mathbf{V}_{\text {oc }} \\
{[\mathbf{m V}]}\end{array}$ & $\begin{array}{c}\mathbf{j}_{\mathbf{s c}} \\
{\left[\mathbf{m A} / \mathbf{c m}^{\mathbf{2}}\right]}\end{array}$ & $\begin{array}{c}\mathbf{F F} \\
{[\%]}\end{array}$ & $\begin{array}{c}\eta \\
{[\%]}\end{array}$ \\
\hline confirmed@ISE & 641 & 35.1 & 80.3 & 18.1 \\
\hline UKN & 642 & 35.3 & 80.3 & 18.2 \\
\hline 10 min@200 $\mathrm{C}$ & 644 & 35.6 & 80.5 & 18.5 \\
\hline 850 min@1 sun & 642 & 35.2 & 80.5 & 18.2 \\
\hline
\end{tabular}

Table 4: History of the best $100 \%$ SoG-Si solar cell.

The independently confirmed measurement at the FhG-ISE CalLab is in good agreement with our results (UKN). A slightly higher current measured at UKN directly after the certified measurement at FhG-ISE is probably the result of an uncorrected spectral mismatch at UKN. The data in table 4 indicate that the measurement at ISE was carried out in the degraded state of the solar cell. Regarding the certificated result we think this solar cell shows an efficiency in the annealed state of $18.4 \%$ (18.5\% measured at UKN), degrading to a stable efficiency of $18.1 \%$ (18.2\% measured at UKN). Similar degradation was observed on solar cells in the $18 \%$ range made of standard block cast mc wafers according to the presented lab-type process [3].

After a short anneal of about 10 minutes at $200^{\circ} \mathrm{C}$ in darkness a fast slight degradation could be observed on a timescale in the order of seconds occurring between two IV measurements in a row. Hereby only $j_{\text {sc }}$ is affected showing a small decrease of about $0.1-0.2 \mathrm{~mA} / \mathrm{cm}^{2}$. $V_{o c}$ remains constant on the same level. The subsequently observed slow slight degradation affects $j_{s c}$ and $V_{o c}$ after several hours of illumination. Both observed degradations are supposed to be boron-oxygen (BO) defect mechanism related.

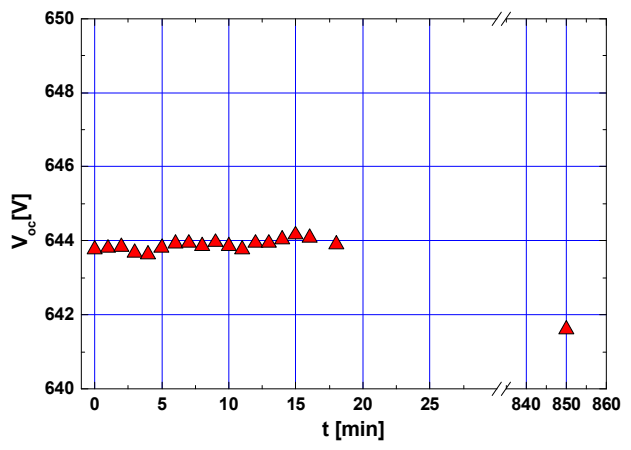

Fig. 9: Degradation curve $\left(25^{\circ} \mathrm{C}, 1\right.$ sun) for the best $100 \%$ SoG-Si solar cell (b).
Bothe et al. reported about a two step degradation mechanism for BO with a fast degradation on the timescale of seconds and a slow degradation on the timescale of hours. The defect generation rate for both is related to the doping concentration. According to [5] for $0.8 \Omega \mathrm{cm}$ the fast degradation rate is about $0.2 \mathrm{~s}^{-1}(\rightarrow \tau=5 \mathrm{~s})$ and about $2 * 10^{-4} \mathrm{~s}^{-1}(\rightarrow \tau=85 \mathrm{~min}$ ) for the slow degradation rate. In addition the fast degradation mainly decreases the bulk lifetimes for low injection levels as for $j_{s c}$ conditions. Lifetimes for higher injection levels as for $V_{\text {oc }}$ conditions are hardly affected for the fast degradation. Therefore the observed slight degradation on the SoG-Si solar cells is in good agreement with the BO related degradation described in [5].

Mainly jo1 seems to be affected by the degradation indicating a degradation of bulk quality keeping $\mathrm{j}_{01}$ at a relative low value as can be seen in table 5 .

\begin{tabular}{|c|c|c|c|c|}
\hline $\begin{array}{c}\text { 2-diode } \\
\text { parameters }\end{array}$ & $\begin{array}{c}\mathbf{j}_{\mathbf{0 1}}{ }^{*} \mathbf{1 0}^{-12} \\
\mathbf{A} / \mathbf{c m}^{\mathbf{2}}\end{array}$ & $\begin{array}{c}\mathbf{j}_{\mathbf{0} 2}{ }^{*} \mathbf{1 0} \\
\mathbf{A} / \mathbf{c m}^{\mathbf{2}}\end{array}$ & $\begin{array}{c}\mathbf{R}_{\mathbf{S e r}} \\
\mathbf{\Omega} \mathbf{c m}^{\mathbf{2}}\end{array}$ & $\begin{array}{c}\mathbf{R}_{\mathbf{S h}^{*} \mathbf{1 0}} \mathbf{}^{\mathbf{6}} \\
\mathbf{\Omega c m}^{\mathbf{2}}\end{array}$ \\
\hline $\mathrm{FZ}$ (d) & 0.52 & 2.4 & 0.35 & 1.9 \\
\hline mc-ann. (d) & 0.43 & 1.7 & 0.53 & 2.5 \\
\hline mc-deg. (d) & 0.49 & 1.7 & 0.43 & 5.7 \\
\hline
\end{tabular}

Table 5: Fitted 2-diode parameters of the Floatzone solar cell (d) and the second best SoG-Si mc solar cell (d) after annealing and degradation.

\section{Solar cells on wafers from an edge brick}

When approaching the edge of an ingot material quality usually decreases. However, large areas of high bulk quality can be found on edge brick wafers suitable for processing solar cells of high quality. Fig. 10 shows a lifetime map of a $125 \times 125 \mathrm{~mm}^{2}$ edge brick wafer measured after $\mathrm{POCl}_{3}$ gettering.

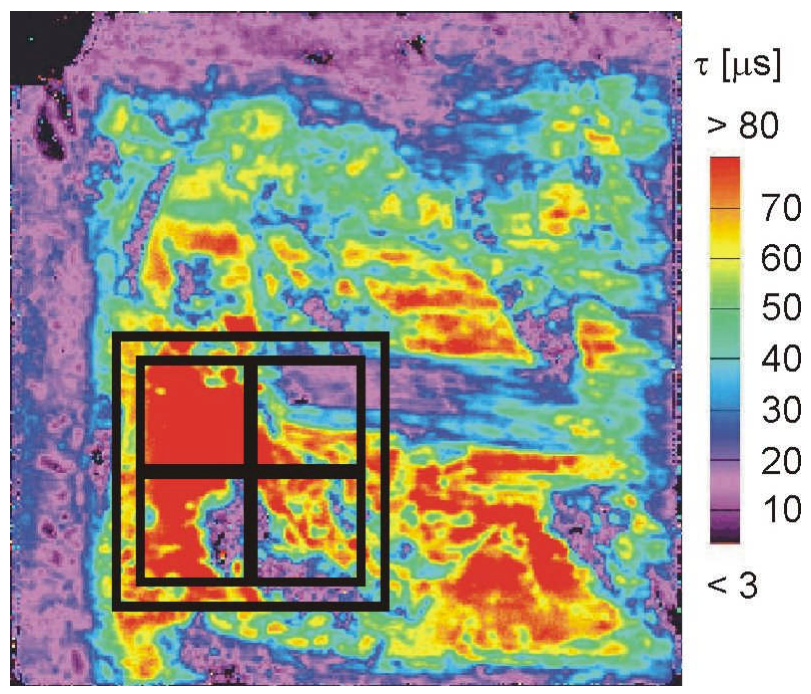

Fig. 10: Bulk lifetime mapping of a $12.5 \times 12.5 \mathrm{~cm}^{2}$ silicon wafer from a block cast edge brick made out of $100 \%$ SoG-Si feedstock. The $5 \times 5 \mathrm{~cm}^{2}$ wafer for the lab-type solar cell process is originating from the marked square. 
Comparing the lifetime maps presented in Fig. 3 and Fig. 10 and regarding the IV results presented in table 2 and 3 at least the solar cell "a" processed out of the $5 \times 5 \mathrm{~cm}^{2}$ wafer marked in Fig. 10 should lead to efficiencies in the $18 \%$ range. As the LBIC map shown in Fig. 11 reveals, solar cell "a" is rather free of efficiency reducing defects in contrast to the LBIC maps of the solar cells presented in Fig. 8. Thus even higher efficiencies and higher $V_{\text {oc }}$ values should be expected. However, as table 6 shows only $16.6 \%$ efficiency (assuming $17.5-17.7 \%$ with a DARC) could be reached instead of $17 \%$ and more. Analysis of a floatzone wafer processed in the same batch reveals an unusually thin Al-BSF of only 2-3 $\mu \mathrm{m}$ depth instead of usually 6-7 $\mu \mathrm{m}$ with the applied Al screen printing plus firing.

This suggests that the performance of the solar cells presented in table 6 is strongly limited by an insufficient AlBSF quality. However, it is remarkable that the solar cells "c" and "d" with a large fraction of visible defects (Fig. 11) would result in the $17 \%$ range with a DARC.
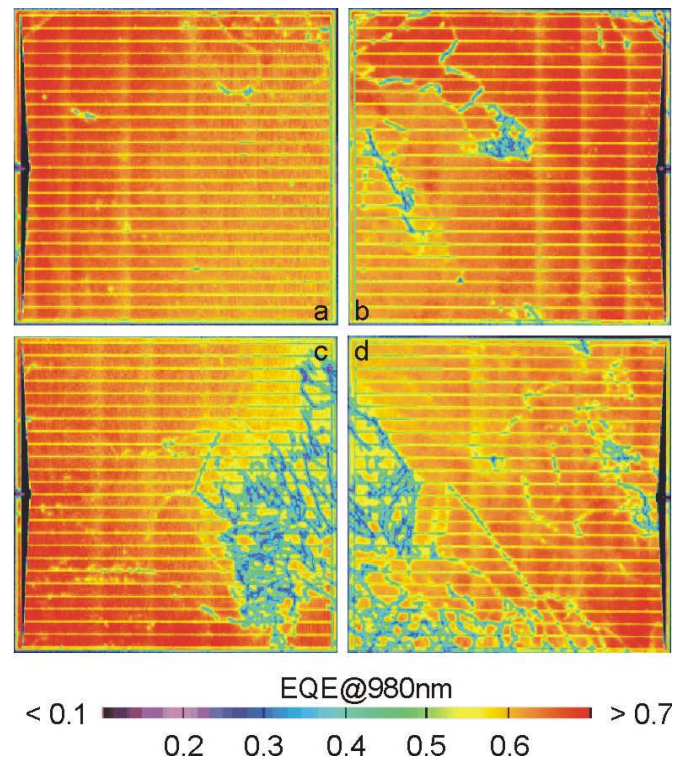

Fig. 11: LBIC maps of 4 lab-type processed solar cells processed out of the $5 \times 5 \mathrm{~cm}^{2}$ wafer illustrated in Fig. 10 with SARC. A good correlation between lifetime map and LBIC map can be seen. The mismatch for solar cell "b" is supposed to an incorrect lifetime measurement in the corresponding area. The obtained vertical features are supposed to be caused by laser intensity fluctuations in the LBIC system.

\begin{tabular}{|c|c|c|c|c|}
\hline $\begin{array}{c}\text { Feedstock } \\
\text { (edge brick) }\end{array}$ & $\begin{array}{c}\mathbf{V}_{\text {oc }} \\
{[\mathbf{m V}]}\end{array}$ & $\begin{array}{c}\mathbf{j}_{\text {sc }} \\
{\left[\mathbf{m A} / \mathbf{c m}^{2}\right]}\end{array}$ & $\begin{array}{c}\mathbf{F F} \\
{[\%]}\end{array}$ & $\begin{array}{c}\boldsymbol{\eta} \\
{[\%]}\end{array}$ \\
\hline $100 \%$ SoG (a) & 633 & 32.9 & 79.9 & 16.6 \\
\hline $100 \%$ SoG (b) & 631 & 32.7 & 79.8 & 16.4 \\
\hline $100 \%$ SoG (c) & 623 & 32.2 & 79.5 & 15.9 \\
\hline $100 \%$ SoG (d) & 625 & 32.5 & 79.2 & 16.1 \\
\hline
\end{tabular}

Table 6: IV data with SiN coating. a-d: see Fig. 11.

\section{SUMMARY}

Results on an industrial type [2] and a lab-type process indicate that the SoG-Si feedstock from Elkem is capable to replace standard feedstock without losing performance for industrial solar cells. The applied lab-scale process is not able to point out the full potential of this material. Reaching $18.4 \%$ efficiency this SoG material equals with $\mathrm{FZ}$ material according to this process. This is the highest reported efficiency $(18.1 \%$ stabilized, independently confirmed) for this material so far. Additionally, the SoG-Si solar cells show unusually high open circuit voltages of up to $644 \mathrm{mV}$ using a full rear side Al BSF fabricated with a standard screen printing technique.

\section{OUTLOOK}

The very promising results on the SoG-Si with Elkem material give motivation to apply an improved solar cell process to this material. The optical performance can be increased by using an isotexture as presented in [2]. A further increase of $j_{s c}$ and $V_{o c}$ can be achieved by the replacement of the full rear side Al-BSF by a local BSF structure. Both approaches should lead to even higher efficiencies.

\section{ACKNOWLEDGEMENTS}

The authors are grateful to Stephan Eisert, Pedro Diaz and Muammer Nalbant from the University of Konstanz for assistance during cell processing and characterisation.

The underlying project of parts of this report was supported with funding of the German BMU under contract number 0327514 . The content of this publication is the responsibility of the authors.

\section{REFERENCES}

[1] K. Peter, R. Kopecek, T. Pernau, E. Enebakk, K. Friestad, R. Tronstad, C. Dethloff, Proc. $31^{\text {st }}$ IEEE PVSC, Lake Buena Vista 2005, p. 927

[2] K. Peter, E. Enebakk, K. Friestad, R. Tronstad, C. Dethloff, Proc. $20^{\text {th }}$ ECPVSEC, Barcelona 2005, $p$. 615

[3] M. Kaes, G. Hahn, A. Metz, Proc. $31^{\text {st }}$ IEEE PVSC, Lake Buena Vista 2005, p. 923

[4] M. Kaes, G. Hahn, Th. Pernau, A. Metz, Proc. $20^{\text {th }}$ ECPVSEC, Barcelona 2005, p. 1063

[5] K. Bothe, J. Schmidt, J. Appl. Phys. 99, 013701 (2006) 